\title{
Efek Terapi Adjuvan Extracorporal Shockwave terhadap Penyembuhan Ulkus Kaki Diabetik Penyandang Diabetes Melitus Tipe 2 dengan Penanda Vascular Endothelial Growth Factor
}

\author{
Harris J. Tampubolon, ${ }^{1}$ Adrian Tangkilisan, ${ }^{2}$ Wega Sukanto, ${ }^{2}$ Grace E. C. Korompis ${ }^{3}$
}

\author{
${ }^{1}$ Program Pendidikan Dokter Spesialis Bagian Ilmu Bedah Fakultas Kedokteran Universitas \\ Sam Ratulangi, Manado, Indonesia \\ ${ }^{2}$ Divisi Bedah Torakovaskular Bagian Ilmu Bedah Fakultas Kedokteran Universitas Sam \\ Ratulangi - RSUP Prof. Dr. R. D. Kandou, Manado, Indonesia \\ ${ }^{3}$ Divisi Kesehatan Masyarakat Bagian Ilmu Bedah Fakultas Kedokteran Universitas Sam \\ Ratulangi, Manado, Indonesia \\ Email: harris.jaya.hjt@gmail.com
}

\begin{abstract}
Diabetic foot ulcer (DFU) prevalence tends to increase every year. Within 30 seconds it is predicted that one leg will be amputated due to DFU. New blood formation triggered by adjuvant extracorporeal shock wave therapy (ESWT) on increasing VEGF level is expected to promote DFU healing. This study was aimed to prove whether ESWT as an adjuvant therapy could stimulate DFU healing by increasing VEGF serum level. This was a quasi-experimental study using two groups, the ESWT and the control groups. Two repeated measurements of VEGF levels and PEDIS scores were performed. The ESWT group (17 patients) received the adjuvant ESWT and the control group (7 patients) received conventional wound care therapy. Both groups received 8-time treatment for 4 weeks. Measurements of VEGF levels and PEDIS scores were performed at baseline and after 4 weeks. The results showed that the PEDIS score of the ESWT group decreased, albeit, not in the control group. The VEGF level of the ESWT group significantly increased (mean rank=13.24) compared to the control group (mean rank=7.33). The Wilcoxon signed-ranks test indicated that the PEDIS score in ESWT group had a significant decrease compared to the control group (mean rank=7.50), $Z=-3.372, p=<.001$. The Pearson correlation test showed a significant relationship between VEGF value and the PEDIS score reduction (81.4\%). In conclusion, the adjuvant ESWT therapy could promote DFU healing (reduced PEDIS score) and increase VEGF levels in DFU patients.
\end{abstract}

Keywords: ESWT; VEGF; diabetic foot ulcer (DFU)

\begin{abstract}
Abstrak: Prevalensi ulkus kaki dibetik (UKD) terus meningkat setiap tahunnya dan dalam 30 detik diprediksi terdapat satu kaki yang diamputasi karena UKD. Pembentukan pembuluh darah baru yang dipicu oleh penggunaan adjuvan ESWT terhadap peningkatan kadar VEGF diharapkan dapat mempercepat penyembuhan UKD. Penelitian ini bertujuan untuk membuktikan terapi adjuvan ESWT dapat meningkatkan kadar VEGF dalam penyembuhan UKD. Jenis penelitan ialah kuasi-eksperimental yang membandingkan dua kelompok perlakuan (ESWT vs kontrol) melalui dua pengukuran berulang terhadap kadar VEGF dan skor pedis. Kelompok ESWT (17 pasien) mendapatkan terapi adjuvan ESWT dan kelompok kontrol (7 pasien) mendapatkan terapi konvensional perawatan luka. Kedua kelompok mendapatkan perlakuan 2 kali per minggu selama 4 minggu. Pengukuran kadar VEGF dan skor pedis pada baseline dan setelah selesai 4 minggu perlakuan. Hasil penelitian mendapatkan penurunan skor PEDIS hanya pada kelompok ESWT (14 pasien), Kadar VEGF kelompok perlakuan didapatkan meningkat bermakna (mean rank=13,24) dibandingkan kelompok kontrol (mean rank=7,33) $(\mathrm{p}<0,001)$. Wilcoxon Signed-Ranks Test mengindikasikan bahwa nilai skor PEDIS kelompok ESWT mengalami penurunan bermakna dibandingkan kelompok kontrol (mean rank=7,0), Z=-3,372, $\mathrm{p}=<0,001$. Uji korelasi Pearson menunjukkan hubungan bermakna antara perubahan nilai VEGF dengan skor pedis $(81,4 \%)$. Simpulan penelitian ini ialah terapi adjuvan ESWT dapat memicu penyembuhan UKD (menurunkan skor PEDIS) dan meningkatkan kadar VEGF pada pasien UKD
\end{abstract}

Kata kunci: ESWT; VEGF; ulkus kaki diabetik (UKD) 


\section{PENDAHULUAN}

Diabetes melitus tipe 2 (DMT2) merupakan salah satu masalah utama dalam sistem kesehatan dan ancaman terhadap kesehatan masyarakat global yang telah meningkat secara dramatis selama dua dekade terakhir Jumlah penyandang DMT2 meningkat dari sekitar 108 juta kasus pada tahun 1980 menjadi 422 juta pada tahun 2014, dan diperkirakan menjadi 578 juta pada tahun 2030. ${ }^{1}$ Indonesia berada pada posisi ke tujuh terbanyak di dunia dengan angka peningkatan prevalensi yang cukup signifikan yaitu dari 6,9\% di tahun 2013 menjadi 8,5\% di tahun 2018 sehingga estimasi jumlah penyandang DMT2 di Indonesia mencapai lebih dari 16 juta orang. ${ }^{2}$ Di Provinsi Sulawesi Utara penyandang DMT2 diprediksi sebanyak 1.813 .975 orang. $^{3}$

Lebih dari $25 \%$ pasien dengan DMT2 akan menderita ulkus kaki diabetikum (UKD) dalam perjalanan hidupnya. Angka amputasi pada ekstremitas bawah untuk populasi pasien DMT2 meningkat 10-20 kali dibandingkan penderita non DMT2 ${ }^{4}$ bahkan setiap 30 detik terdapat satu kaki yang diamputasi karena UKD di seluruh dunia. ${ }^{5}$

Penyebab terjadinya UKD melibatkan banyak faktor; umumnya disebabkan oleh mikroangiopati dan berhubungan dengan neuropati perifer dan juga infeksi ${ }^{5}$ sehingga memerlukan waktu penyembuhan lama dan penanganan multidisiplin yang komprehensif, berawal dari kontrol kadar gula darah, penggunaan antibiotik, debrideman ulkus, perawatan luka, serta off loading dan revaskularisasi pada ulkus diabetik iskemik. ${ }^{6}$ Terdapat beberapa terapi yang digunakan untuk memicu penyembuhan UKD di antaranya terapi oksigen hiperbarik, teknik vakum, dan terapi laser tegangan rendah, namun sampai saat ini belum disepakati terapi yang memuaskan ${ }^{7} \mathrm{Hal}$ ini mendorong pencarian metode untuk memicu percepatan penyembuhan UKD yang mudah digunakan, non-invasif, tanpa efek samping, dan biaya lebih murah; terapi yang dapat menjadi pilihan ialah extracorporeal shockwave therapy (ESWT). ${ }^{8}$

Sebagai terapi adjuvan pada UKD, ESWT bekerja dengan pemberian stimuli fisik secara mekanotransduksi pada luka yang direspon oleh tubuh dengan mengeluarkan sinyal kimiawi berupa peningkatan kadar vascular endotelial growth factor (VEGF) yang memicu proses angiogenesis, dan meningkatkan perfusi darah ke jaringan sehingga luka lebih cepat membaik. ${ }^{9}$ Peran ESWT dalam peningkatkan kadar VEGF untuk memicu penyembuhan UKD pada penyandang DMT2 mendorong penulis untuk meneliti lebih lanjut agar memperoleh gambaran lebih jelas terhadap efek yang ditimbulkannya.

\section{METODE PENELITIAN}

Penelitian ini menggunakan metode quasi-experimental yang membandingkan dua kelompok perlakuan (ESWT vs kontrol) melalui dua pengukuran berulang terhadap outcome, yakni kadar VEGF dan skor PEDIS. Kelompok kontrol menerima terapi konvensional UKD yang meliputi perawatan konvensional luka, sedangkan kelompok ESWT mendapatkan sesi terapi ESWT, yaitu dua kali perminggu selama empat minggu. Pengukuran VEGF dilakukan pada baseline dan setelah ESWT pada kelompok terapi. Kriteria inklusi untuk subjek penelitian ialah: a) Skor PEDIS (Perfusion, Extent, Depth, Infection, and Sensation) $\leq 7$; b) Kadar hemoglobin ( $\mathrm{Hb}) \geq 8$ g\%; c) Subjek bersedia mengikuti proses terapi ESWT yang diberikan dan dieklusikan bila terdapat keaadaan yang direncanakan untuk tindakan operatif pada luka; kadar albumin $<2 \mathrm{gr} / \mathrm{dl}$; ABI (ankle-brachial index) <0,6; menderita gangguan neurologik atau sedang hamil.

Analisis bivariat dilakukan dengan tes Mann-Whitney U untuk melihat hubungan antara dua sampel yang tidak berpasangan (ESWT dan kontrol) untuk setiap variabel kontinu. Perbedaan kadar serum VEGF dan skor PEDIS pada setiap kelompok perlakuan (terapi ESWT dan terapi konvensional) dianalisis dengan menggunakan uji Wilcoxon signed-ranks test untuk melihat perbedaan nilai sebelum dan sesudah terapi. Hubungan antara perubahan nilai skor pedis dan VEGF dianalisis dengan uji korelasi Pearson. Analisis regresi multivariat dilakukan untuk melihat faktor-faktor yang meme- 
ngaruhi perubahan nilai VEGF dengan nilai signifikansi 0,05. Analisis dilakukan dengan menggunakan program SPSS 28.0.

Penelitian ini telah mendapat persetujuan dari Komisi Etik Penelitian Kesehatan RSUP Prof. Dr. R. D. Kandou Manado, dengan nomor keterangan layak etik yaitu No. 079/EC/KEPK-KANDOU/V/2021.

\section{HASIL PENELITIAN}

Penelitian ini dilaksanakan di Bagian Bedah RSUP Prof. Dr. R. D. Kandou Mana- do sejak bulan Januari hingga Juli 2021 dengan subjek sebanyak 24 orang.

Tabel 1 memperlihatkan bahwa sebagian besar subyek penelitian berjenis kelamin laki-laki (11 orang), dengan rerata usia yang tidak jauh berbeda antara kelompok ESWT dan kontrol.

Tabel 2 memperlihatkan bahwa terdapat beberapa perbedaan bermakna pada gambaran hematologik antara kelompok ESWT dan kelompok kontrol yang dianalisis dengan uji Mann-Whitney U.

Tabel 1. Perbandingan distribusi jenis kelamin dan usia antara kelompok ESWT dan kontrol

\begin{tabular}{llccc}
\hline & & ESWT $(\%)$ & Kontrol $(\%)$ & Total \\
\hline Jenis kelamin & Laki-laki & $9(52,9)$ & $2(28,6)$ & 11 \\
& Perempuan & $8(47,1)$ & $5(71,4)$ & 13 \\
\multirow{3}{*}{ Usia } & Total & $17(100)$ & $7(100)$ & 24 \\
& Mean & 48,59 & 48,86 & \\
& SD & 4,17 & 4,26 & \\
& Min & 43 & 43 & \\
& Max & 56 & 55 & \\
\hline
\end{tabular}

Tabel 2. Perbandingan lama ulkus, gambaran hematologik, dan ada-tidaknya hipertensi antara kelompok ESWT dan kontrol

\begin{tabular}{lccc}
\hline Parameter & \multicolumn{2}{c}{ Kelompok } & Nilai p* \\
& ESWT & Kontrol & \\
\hline Lama ulkus & 2,4 & 2,0 & 0,1913 \\
HB & 12,3 & 14,6 & 0,0172 \\
Eritrosit & 4,1 & 5,0 & $0,0241^{* * *}$ \\
Leukosit & $11.167,0$ & $13.985,7$ & $0,0069 * * *$ \\
Trombosit & $275.347,1$ & $210.142,9$ & 0,0527 \\
HCT & 37,2 & 40,8 & 0,3909 \\
PT & 11,2 & 15,7 & $0,0028 * * *$ \\
APTT & 30,0 & 31,4 & 0,1716 \\
INR & 1,5 & 6,2 & 0,7264 \\
SGOT & 30,4 & 37,4 & 0,0525 \\
SGPT & 48,4 & 24,3 & 0,3729 \\
Ureum & 24,5 & 25,4 & 0,8730 \\
Creatinine & 0,8 & 0,9 & 0,2503 \\
Na & 145,4 & 135,9 & $0,0060 * * *$ \\
K & 4,0 & 3,9 & 0,5248 \\
Cl & 102,1 & 97,9 & $0,0033 * * *$ \\
GDS & 201,1 & 202,1 & 0,8988 \\
Albumin & 3,1 & 3,0 & 0,5026 \\
Hipertensi & & & 0 \\
***menunjukkan perbedaan bermakna & &
\end{tabular}


Tabel 3 dan Tabel 4 memperlihatkan gambaran nilai skor PEDIS dan VEGF pada kelompok kontrol dan kelompok ESWT. Pada kelompok kontrol tidak didapatkan penurunan skor PEDIS dan peningkatan nilai VEGF hanya sebesar 11,7. Pada kelompok ESWT didapatkan penurunan skor PEDIS dengan rerata penurunan 1,29 dan peningkatan nilai rerata VEGF mencapai 114,7.

Gambar 1 dan 2 memperlihatkan hasil pengukuran skor PEDIS dan VEGF sebelum dan sesudah terapi ESWT. Terdapat tiga subyek yang tidak mengalami perubahan skor pedis dan juga tiga subyek yang mengalami penurunan nilai VEGF.

Uji beda berpasangan non parametrik (Wilcoxon signed-ranks test) mengindikasi- kan bahwa nilai skor pedis kelompok ESWT (mean rank=0,00) mengalami penurunan bermakna dibandingkan nilai skor PEDIS pada kelompok kontrol (mean rank=7,50), $\mathrm{Z}=-3,372, \mathrm{p}=<0,001$. Selain itu didapatkan bahwa nilai VEGF kelompok ESWT (mean rank=13,24) mengalami peningkatan bermakna dibandingkan nilai VEGF kelompok kontrol (mean rank=7,33), dengan $\mathrm{Z}=$ =$3,658, \mathrm{p}=<0,001$.

Hasil uji korelasi Pearson dengan metode bootstrap memperlihatkan adanya hubungan bermakna antara perubahan nilai VEGF dan skor PEDIS dengan nilai $\mathrm{p}=<0,001$ dan CI $95 \%=0,603-0,927$, serta nilai korelasi $81,4 \%$ (sangat kuat).

Tabel 3. Hasil pengukuran nilai VEGF dan skor pedis pada kelompok kontrol

\begin{tabular}{llcc}
\hline Parameter & Nilai & \multicolumn{2}{c}{ Pengukuran } \\
\cline { 3 - 4 } & & Sebelum & Sesudah \\
\hline Skor PEDIS & Mean & 6 & 6 \\
& Median & 6 & 6 \\
& SD & 0,58 & 0,58 \\
& Min & 5 & 5 \\
VEGF & Max & 7 & 7 \\
& Mean & 923,5 & 935,2 \\
& Median & 925,4 & 934,5 \\
& SD & 68,14 & 68,57 \\
& Min & 794 & 803 \\
& Max & 1016 & 1025 \\
\hline
\end{tabular}

Tabel 4. Hasil pengukuran nilai VEGF dan skor pedis pada kelompok ESWT

\begin{tabular}{llcc}
\hline Parameter & Nilai & \multicolumn{2}{c}{ Pengukuran } \\
\cline { 3 - 4 } Skor PEDIS & Mean & Sebelum & Sesudah \\
& Median & 5,1 & 3,8 \\
& SD & 0,86 & 4 \\
& Min & 4 & 0,53 \\
VEGF & Max & 6 & 3 \\
& Mean & 687,7 & 5 \\
& Median & 694,1 & 802,4 \\
& SD & 66,13 & 798,4 \\
& Min & 563 & 63,66 \\
& Max & 789 & 925
\end{tabular}




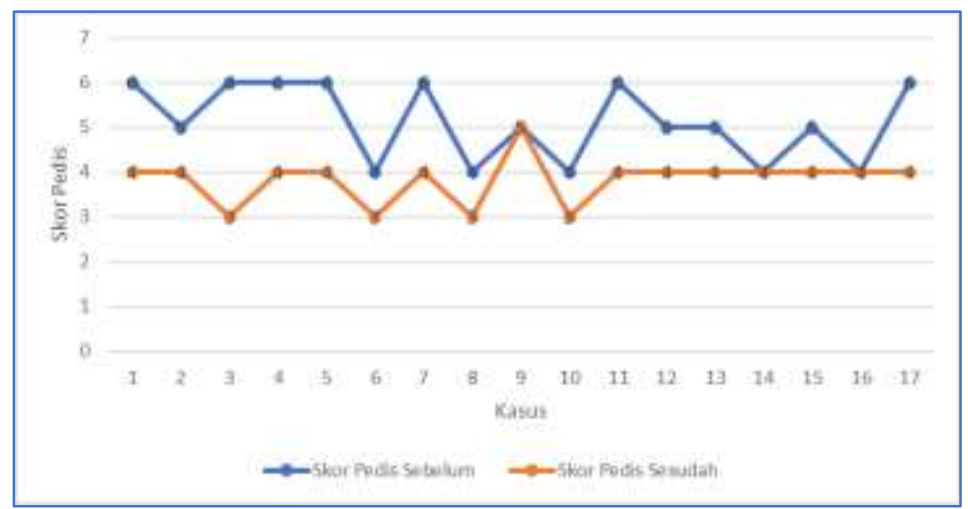

Gambar 1. Hasil pengukuran skor PEDIS sebelum dan sesudah pemberian terapi ESWT

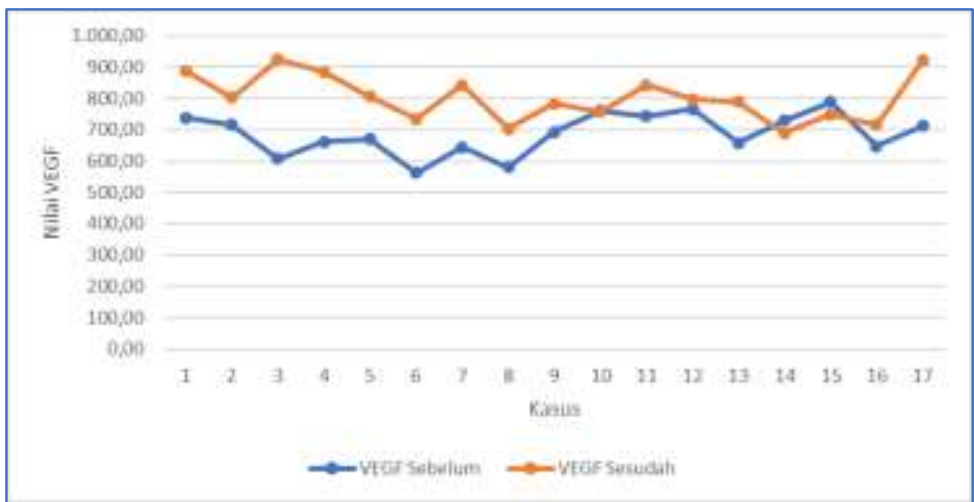

Gambar 2. Hasil pengukuran nilai VEGF sebelum dan sesudah pemberian terapi ESWT

Uji hubungan antara kelompok (ESWT dan kontrol) dengan perubahan nilai skor PEDIS dan VEGF (analisis bivariat) dilanjutkan untuk mencari hubungan dengan co-variate lainnya dan didapatkan perbedaan bermakna antara perlakuan/tindakan dengan perubahan nilai VEGF ( $\mathrm{p}=0,014)$.

Analisis statistik dilanjutkan dengan analisis regresi binomial untuk melihat pengaruh jenis tindakan terhadap perubahan skor pedis dan nilai VEGF dengan keberadaan variabel lain, dan didapatkan parameter lainnya secara bersamaan tidak memengaruhi perubahan nilai VEGF jika dihubungkan dengan jenis tindakan yang dilakukan.

\section{BAHASAN}

Penelitian mengenai strategi yang tepat untuk mengatasi kesulitan penyembuhan luka pada pasien diabetes telah banyak dilakukan, namun proses penyembuhan luka yang tidak berlangsung dengan baik masih menjadi salah satu faktor utama yang meningkatkan angka morbiditas pada pasien UKD. ${ }^{10}$ Iskemia jaringan disebabkan oleh proses neovaskularisasi yang tidak adekuat dipercaya menjadi faktor yang menimbulkan terganggunya proses penyembuhan UKD. ${ }^{11}$ Oleh karena itu pada penelitian ini dievaluasi pengaruh terapi adjuvan ESWT terhadap penyembuhan UKD yang dinilai dari penurunan skor PEDIS dan juga proses neovaskularisasi yang dinilai dari peningkatan VEGF serum.

Penelitian dilakukan terhadap penderita UKD yang memenuhi kriteria penelitian dengan memberikan persetujuan. Rekrutmen pasien berlangsung selama masa pengumpulan data hingga jumlahnya memenuhi perhitungan besar sampel. Subyek penelitian dibagi menjadi dua kelompok, terdiri dari: kelompok yang mendapatkan perlakuan terapi adjuvan ESWT, terdiri dari 17 orang (9 laki-laki dan 8 perempuan) dan kelompok kontrol yang mendapatkan pera- 
watan luka konvensional (2 orang laki-laki dan 5 orang perempuan). Rerata usia kelompok perlakuan 48,59 tahun dan kelompok kontrol 48,6 tahun.

Semua kelompok mendapatkan terapi sebanyak 8 kali selama 4 minggu. Penilaian skor PEDIS dan VEGF dilakukan pada awal dan akhir terapi untuk membandingkan hasil sebelum dan sesudah pemberian terapi adjuvan ESWT maupun terapi perawatan luka konvensional. Rerata lamanya UKD yang sudah diderita sebelum mengikuti penelitian tidak memiliki perbedaan bermakna antara kedua kelompok yaitu pada kelompok ESWT 2,4 bulan dan pada kelompok kontrol 2 bulan. Demikian pula halnya pada indikator hematologik; yang terlihat berbeda bermakna hanya pada nilai eritrosit, leukosit, natrium, dan klorida.

Pada penilaian klinis UKD dengan menggunakan skor PEDIS didapatkan gambaran yang membaik pada kelompok ESWT sedangkan pada kelompok kontrol didapatkan gambaran klinis UKD tidak terlalu banyak perubahan. Pada kelompok perlakuan hanya terdapat tiga orang yang tidak mengalami penurunan skor PEDIS. Pada kelompok ini didapatkan rerata skor PEDIS sebelum diberikan terapi adjuvan ESWT sebesar 5,1 dan setelah diberikan terapi ESWT reratanya menurun menjadi 3,8. Hal ini menunjukkan rerata skor PEDIS mengalami penurunan sebesar 1,29. Pada kelompok kontrol semua pasien tidak mengalami penurunan skor PEDIS. Hasil ini sejalan dengan penelitian yang dilakukan Jeppesen et $\mathrm{al}^{12}$ yang melaporkan adanya perbaikan UKD dengan pemberian ESWT, namun menggunakan parameter yang berbeda yaitu penurunan ukuran luka dan peningkatan perfusi oksigen, serta waktu pemberian terapi yang lebih lama yaitu selama 7 minggu. Perbaikan UKD secara klinis dengan pemberian adjuvan terapi ESWT juga selaras dengan penelitian yang dilakukan oleh Speed et $\mathrm{al}^{13}$ yang menyatakan bahwa cara kerja ESWT memicu stimulus pada tingkat sel untuk dilanjutkan pada proses penyembuhan luka kronis.

Subyek penelitian pada kelompok ESWT yang tidak mengalami penurunan skor PEDIS dapat disebabkan oleh beberapa faktor antara lain jalur rangsangan yang diberikan oleh ESWT hanya memengaruhi satu jalur proses penyembuhan saja sedangkan jalur lain (jalur polyol dan jalur hexosamine) tidak mengalami perubahan. ${ }^{14}$ Faktor lainnya yang mungkin memengaruhi ialah lamanya pemberian terapi adjuvan ESWT dimana pada penelitian ini hanya diberikan selama 4 minggu, sedangkan pada beberapa penelitian lainnya diberikan selama 3-8 minggu. ${ }^{12}$

Proses angiogenesis yang dipicu oleh peningkatan kadar VEGF sehingga terbentuk pembuluh darah baru dan pada akhirnya menjadikan luka kronis membaik menjadi tujuan pada penelitian ini. Zhou et $\mathrm{al}^{15}$ menyatakan bahwa VEGF merupakan salah satu faktor pertumbuhan yang memicu angiogenesis, meningkatkan permeabilitas kapiler, meningkatkan perfusi darah dan metabolisme pada jaringan yang pada akhirnya memicu penyembuhan luka kronis.

Hasil penelitian ini memperlihatkan bahwa nilai VEGF pada kelompok ESWT maupun kelompok kontrol mengalami kenaikan, namun yang menarik ialah pada kelompok yang diberikan terapi adjuvan ESWT didapatkan kenaikan nilai VEGF rerata sebesar 114,75 sedangkan pada kelompok yang diberikan terapi perawatan luka konvensional kenaikan nilai VEGF rerata hanya sebesar 11,67. Demikian halnya hasil yang didapat melalui uji beda berpasangan non-parametrik (Wilcoxon signed-ranks test) yang mengindikasikan bahwa nilai VEGF kelompok ESWT (mean rank=13,24) mengalami peningkatan bermakna dibandingkan nilai VEGF pada kelompok kontrol (mean rank=7,33), $\mathrm{Z}=-3,658, \mathrm{p}=<0,001$. Berdasarkan hasil analisis statistik ini didapatkan gambaran bahwa terapi adjuvan ESWT efektif meningkatkan kadar VEGF pada penderita UKD.

Hasil serupa dilaporkan pada penelitian Chen et $\mathrm{al}^{16}$ yang menggunakan hewan coba dan mendapatkan ekspresi VEGF meningkat pada hari ke-10 setelah pemberian dua sesi terapi ESWT yang memicu pembentukan pembuluh darah baru dan secara klinis luka mengalami penyembuhan lebih cepat 
dibandingkan kelompok kontrol.

Nilai korelasi antara perubahan nilai VEGF dengan penurunan skor PEDIS (uji korelasi Pearson) sebesar 81,4\% (sangat kuat) menunjukkan bahwa semakin besar kenaikan nilai VEGF maka akan semakin besar pula penurunan skor PEDIS. Pengaruh tindakan terapi ESWT terhadap perubahan nilai skor PEDIS dan VEGF secara statistik juga didapatkan perbedaan bermakna $(\mathrm{p}<0,001)$ yang menunjukkan bahwa pemberian terapi adjuvan ESWT dapat meningkatkan kadar VEGF dan menimbulkan penyembuhan UKD yang dinilai dengan menurunnya skor PEDIS.

\section{SIMPULAN}

Terapi adjuvan ESWT meningkatkan kadar VEGF dan memicu perbaikan ulkus kaki diabetikum (menurunkan skor PEDIS).

\section{Konflik Kepentingan}

Penulis menyatakan tidak terdapat konflik kepentingan dalam studi ini.

\section{DAFTAR PUSTAKA}

1. Bin Z, Yuan L, Kaveh H, James B, Mariachiara DC, Goodarz D, et al. Worldwide trends in diabetes since 1980: a pooled analysis of 751 population-based studies with 4.4 million participants. Lancet. 2016;387 (10027):1513-30.

2. Saeedi P, Petersohn I, Salpea P, Malanda B, Karuranga S, Unwin N, et al. Global and regional diabetes prevalence estimates for 2019 and projections for 2030 and 2045: results from the International Diabetes Federation Diabetes Atlas, 9th edition. Diabetes Res Clin Pract. 2019; 157:107843.

3. Balai Data Penelitian dan Pengembangan Kesehatan Dinas Kesehatan Daerah Provinsi Sulawesi Utara. Profil Kesehatan Provinsi Sulawesi Utara tahun 2016. Dinas Kesehatan Daerah Provinsi Sulawesi Utara; 2017.

4. Nouvong A, Armstrong DG. Diabetic foot ulcers. In: Cronenwett JL, Johnston KW, editors. Rutherford's Vascular Surgery (8th ed). Philadelphia: Elsevier Saunders, 2014.

5. Vijayakumar V, Samal SK, Mohanty S, Nayak SK. Recent advancements in biopoly- mer and metal nanoparticle-based materials in diabetic wound healing management. Int $\mathbf{J}$ Biol Macromol. 2019;122:137-48. Doi: 10.1016/j. ijbiomac.2018.10.120. Epub 2018 Oct 18. PMID: 30342131.

6. Kessler L, Bilbault P, Ortega F, Grasso C, Passemard R, Stephan D. Hyperbaric oxygenation accelerates the healing rate of nonischemic chronic diabetic foot ulcers: a prospective randomized study. Diabetes Care. 2003;26(8):2378-82.

7. Maria Carmignano, S. Extracorporeal Shock Wave Therapy in Chronic Wound Care. Physical Therapy Effectiveness. (2020) doi:10.5772/intechopen.89592

8. Wang CJ, Cheng JH, Kuo YR, Schaden W, Mittermayr R. Extracorporeal shockwave therapy in diabetic foot ulcers. Int J Surg. 2015;24(PtB):207-9. Doi: 10.1016/j.ijsu. 2015.06.024. Epub 2015 Jun 12. PMID: 26079500.

9. Lipsky BA, Berendt AR, Cornia PB, Pile JC, Peters EJG, Armstrong DG, et al.2012 Infectious Diseases Society of America Clinical Practice Guideline for the diagnosis and treatment of diabetic foot infections. J Am Podiatric Med Assoc. 2013;103(1):27.

10. Zhang L, Weng C, Zhao Z, Fu X. Extracorporeal shock wave therapy for chronic wounds: A systematic review and meta-analysis of randomized controlled trials. Wound Repair Regen. 2017;25(4):697-706. Doi: 10.1111/wrr. 12566. Epub 2017 Oct 18. PMID: 28759136.

11. Das SK, Yuan YF, Li MQ. An overview on current issues and challenges of endothelial progenitor cell-based neovascularization in patients with diabetic foot ulcer. Cellular Reprogram, 2017;19(2): 75-87.

12. Jeppesen SM, Yderstraede KB, Rasmussen BS, Hanna M, Lund L. Extracorporeal shockwave therapy in the treatment of chronic diabetic foot ulcers: a prospective randomised trial. $\mathrm{J}$ Wound Care. 2016;25(11):641-9. Doi:10.12968/jowc.2016.25.11.641. PMID: 27827284

13. Speed C. A systematic review of shockwave therapies in soft tissue conditions: focusing on the evidence. Br J Sports Med. 2014;48(21):1538-42. 
Doi:10.1136/bjsports-2012-091961. Epub 2013 Aug 5. PMID: 23918444.

14. Patel S, Srivastava S, Singh MR, Singh D. Mechanistic insight into diabetic wounds: Pathogenesis, molecular targets and treatment strategies to pace wound healing. Biomed Pharmacother. 2019; 112:108615. Doi: 10.1016/j.biopha. 2019. 108615. Epub 2019 Feb 20. PMID: 30784919.

15. Zhou K, Ma Y, Brogan MS. Chronic and nonhealing wounds: The story of vascular endothelial growth factor. Med Hypo- theses. 2015;85(4):399-404.

Doi:10.1016/j.mehy.2015.06.017. Epub 2015 Jun 26. PMID: 26138626

16. Chen RF, Chang CH, Wang CT, Yang MY, Wang CJ, Kuo YR. Modulation of vascular endothelial growth factor and mitogen-activated protein kinase-related pathway involved in extracorporeal shockwave therapy accelerate diabetic wound healing. Wound Repair Regen. 2019;27(1):69-79.

Doi:10.1111/wrr. 12686. Epub 2018 Dec 7. PMID: 30394625 